\title{
Factors Affecting the Application of the Concept of Green Marketing: An Empirical Study in Saudi Food Industry Companies
}

\author{
Nof Hazem Alabdali \\ King Abdul-Aziz University \\ Jeddah \\ Saudi Arabia
}

\begin{abstract}
This research is aiming at investigating the factors affecting the adoption of green marketing in food industry companies in Saudi Arabia and the level of their adoption of green marketing concept. Four factors are examined: environmental protection legislation, shortage of natural resources, consumer behavior, and attitudes of senior management toward green marketing. To achieve the research objectives, four hypotheses have been developed and empirically tested using descriptive and inferential statistics method. Data was collected by administering a questionnaire to a sample of (70) companies operating in food industry in Jeddah, Saudi Arabia. Hypotheses testing results show a statistically strong relationship between all independent variables and adoption of green marketing by food companies except the variable of consumer behaviors, it has no significant relationship with the adoption of green marketing. In addition, results show a low level of adoption of green marketing in four marketing mix dimensions by Saudi food companies.
\end{abstract}

Keywords: Green Marketing - Sustainable Development - Social Responsibility

\section{Introduction}

Recently, from a social and ethical responsibility perspective, environmental awareness has increased at various levels around the world. One of the main reasons for this increase is the rise in pollution levels, ozone layer depletion, global warming, and the disproportionate use of natural resources due to irresponsible industrialization in organizations. As a result of these global developments, many agencies and organizations have emerged the call for the preservation of the environment to make it a safe place for present and future generations to live in.

Under these circumstances, new concepts, such as social marketing, green marketing, and sustainable marketing, have emerged. These concepts are theoretically considered synonymous (Anand, 2014). Researchers also determined that 'Green marketing' was the most common of the conceptual terms. Green marketing is defined as "the development of more environmentally safe products" (Kotler, 1999). It is also defined as "the processes of development, pricing and promotion of products that do not harm the environment" (Dibb et al., 2005).

Green marketing is considered a new concept that focuses on the optimal use of resources. It aims to provide the best value to customers as well as other interested parties, while taking into consideration the long-term environmental and social needs. In addition, due to the widespread knowledge and campaign on weather-related disasters, consumers around the globe are becoming increasingly sensitive to environmental conservation. This situation has forced firms to adapt their practices to respect the demands of the green consumer by incorporating sustainability principles into their marketing mix (Caprita, 2015).

The increasing emphasis on environmental sustainability presents firms with several ethical dilemmas, especially since meeting eco-friendly business requirements is costly. For instance, would it be ethically right for a firm to engage in practices that promote environmental sustainability even if they jeopardize its survival, or would it be morally right for a company to enhance its survival while endangering ecological stability? Green marketing strategies provide organizations with opportunities to harmonize the two views. It enables them to realize reasonable profits while protecting the environment. The practice of the concept of green marketing requires going back to the elements of the marketing mix and determining the role of a set of factors that affect the level of adoption of the concept by organizations (Kirgiz, 2016). Therefore, this study is intended to investigate the role of these factors, which include legislations for pollution and environmental protection, scarcity and high cost of natural resources, changes in consumer behavior and trends, and the attitudes of senior management towards green marketing; and it measures the level of adoption by the Saudi food industries companies towards this concept. 


\subsection{Problem Statement}

On spite of rapid growing of popularity of green marketing strategies and application in the world, only a few studies have examined the factors that affect green marketing in food industry. For example, AlFuqaha and AlSaifi, (2015) conducted a study to investigate the role of factors affecting the adoption of sustainable marketing by food industrial companies in Palestine. These factors are regulations on environmental protection legislation, shortage of natural resources, the change in consumer behavior, and attitudes of senior management toward sustainable marketing. Results showed that there was a statistically strong relationship between all these factors and adoption of sustainable marketing by food industrial companies except the variable of consumer behaviors which has no significant relationship with the adoption of sustainable marketing.

In addition, there remains a shortcoming in studies in the Kingdom of Saudi Arabia (KSA) to determine why some companies are better than others in applying and practicing the concept of green marketing. Herein lies the problem of the research; this study investigates the factors that affect the adoption of green marketing concept in food industry. Based on AlFuqaha and AlSaifi, (2015), these factors include environmental protection legislation, shortage of natural resources, changes in consumer behavior, and the attitudes of senior management towards green marketing. The research also investigates the level of adoption of green marketing by Saudi food industry.

\subsection{Objectives of the study}

The main objective of the current research is to identify the factors affecting the adoption of green marketing in Saudi food industries companies. Moreover, this research aims to achieve the following objectives: understand the extent to which Saudi food industries companies adopt green marketing, determine the role of each factor that affect the level of adoption of green marketing, and help decision makers by making recommendations that help them adopt and implement green marketing strategies.

\subsection{Significance of the study}

Currently, researchers are still searching for a set of factors that drive the adoption of the concept of green marketing. It is still unclear why some companies perform better than others in applying and practicing this concept. This research will help clarify the most important factors affecting the adoption of the concept of green marketing in the business organizations targeted in this study; given that there is a global focus on issues regarding environmental protection and avoiding environmental damage. The importance of this study stems from the need for companies in KSA to have clear directives and mechanisms that aid them towards becoming socially responsible organizations. The results of this research will provide important information that will help make the right strategic decisions across the Saudi food manufacturing industry. This research will also serve to achieve KSA's Vision (2030) in terms of applying the principle of environmental sustainability. This study will open up broad prospects for new studies about green marketing and their importance in achieving competitive advantage and environmental conservation.

\subsection{Hypothesis of the study}

2. Environmental protection legislations have no significant effect on adoption green marketing in Saudi food industry companies.

3. Shortage of natural resources has no significant effect on adoption green marketing in Saudi food industry companies.

4. Consumer behavior have no significant effect on adoption green marketing in Saudi food industry companies.

5. The attitude of senior management has no significant effect on adoption green marketing in Saudi food industry companies.

\subsection{Research Model}




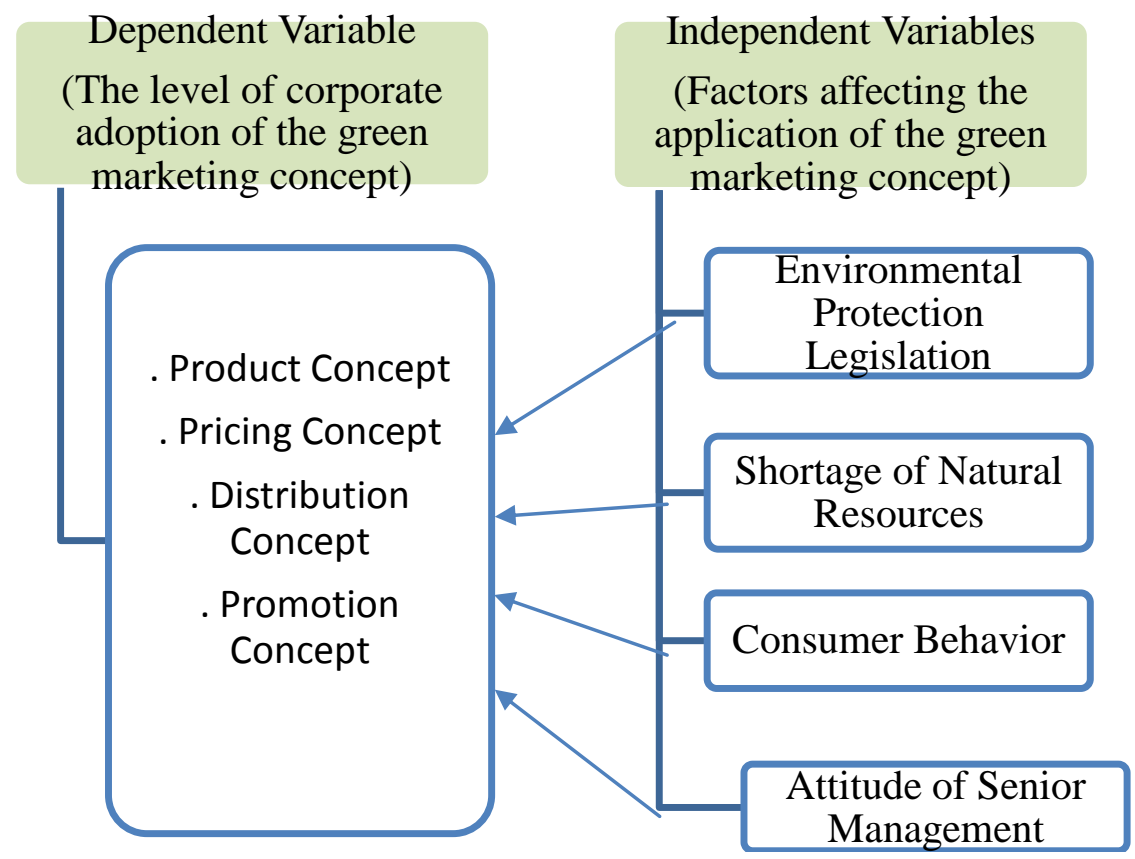

\section{Literature review}

Figure 1: Research Model

\subsection{Green Marketing}

Green marketing denotes creating, promoting, determining prices, and distributing commodities that cause minimal or no harm to the natural ecosystem (Baker \& hart, 2008). Strategies include changing production process, product modification, or evolving promotion tactics (Solaiman et al., 2015). The origin of the concept dates back to the 1970s with the emergence of green marketing, which focused on factories that had severe impacts on the environment (Baker \& Hart, 2008). It was also during this time that increasing emphasis was placed on corporate social responsibility (CSR) (Dibb et al., 2005). The period beginning the early 1990s was characterized by the rising awareness and interest in eco-friendly products, leading to the emergence of the concepts of the green consumer. Since then, the idea of green marketing has attracted the attention of scientists, environmentalists, firms, and the public (Baker \& Hart, 2008).

At present, green marketing continues to receive increasing attention as corporations strategize themselves to enhance their survival; the dynamics that have led to this pattern include the growing number of eco-sensitive consumers, rising government pressures, and increasing environmentalist campaigns toward a green economy (Garg, 2015). Nevertheless, the adoption of green techniques by firms remains low as they struggle to balance environmental needs with their economic responsibility (Alam et al., 2012).

Corporations that incorporate green philosophies have several competitive advantages over their non-green equivalents (Eneizan, et al., 2015). Analysts group these benefits into five categories: as a business opportunity, social responsibility, those related to government pressures, cost/ profit issues, and those associated with competitive pressure (Anand, 2014). In fact, Green marketing is an integration of several concepts including social marketing, corporate social responsibility (CSR), and sustainable development (Anand, 2014).

\subsection{Green Marketing and the Marketing Mix}

Green marketers are rapidly adopting the conventional approach to marketing (the 4Ps): product, price, place and promotion; which refereed as marketing mix (Caprita, 2015).

\subsubsection{Product}

Despite the increasing effort to make green products appeal to many people, their market share is still low (Foster, 2013). A primary reason for this situation is that the principal target for most marketers remain to be the green consumer (Kirgiz, 2016). Most of these products are usually made from used or recycled goods to save energy, cost, and minimize environmental harm. Manufacturers need to consider both the economic and ecological aspects of the product during its design (Solaiman et al., 2015; Čerkasov et al., 2017). In this regard, the concept of green chemistry is receiving increasing attention to help developers meet these two essential needs (Alam et al., 2012; Baker \& Hart, 2008). 


\subsubsection{Price}

In determining the price of eco-friendly products, marketers account for the environment, people, and profit (Solaiman et al., 2015). Value addition is usually through modifying functionality, appearance, or by customization. In most instances, the prices for green commodities are mostly higher than those for conventional items (Widyastuti \& Santoso, 2016). In the view of Solaiman et al. (2015), individuals are willing to pay a price that is up to 20 percent higher than that of non-green products. However, Sima (2014) noted that such claims are not the real manifestation of their attitude or behavior toward paying premiums for green products. Since cost is a crucial determinant when purchasing a good or service, green manufacturers need to design them such that the consumer appreciates other potential benefits beyond cost consideration. Realizing this goal is possible if marketing campaigns promote intrinsic ethics and moral intensity (Sima, 2014; Foster, 2013).

\subsubsection{Place (Distribution)}

Green distribution strategies usually aim at minimizing green emissions during transport. Retailers play essential roles in this regard. They usually share the responsibility for the manufacturers' claims about their products (Solaiman et al., 2015; Foster, 2013). Working with channel partners to develop product reuse or disposal arrangements and ensuring that customers are able to return recyclable materials are two tactical ways that firms could apply in their pursuit of green distribution (Eneizan et al., 2015).

\subsubsection{Promotion}

Green product marketers use different promotion tools to sensitize their potential clients on the benefits of their products (Foster, 2013). Sales promotions, direct marketing, public relations, and advertising are some of the means of conveying to the customers the core message of greenness (Eneizan et al., 2015). The aim of such campaigns should be to persuade consumers to modify their perception concerning green commodities. A primary issue in this regard is the use of related terms that may be confusing to consumers (Solaiman et al., 2015). Companies aiming to make their products appealing should develop strategies that will help potential users to comprehend the terms (Foster, 2013).

\subsection{Factors effecting the adoption of Green Marketing in food industry}

Based on AlFuqaha and AlSaifi, (2015), this study is intended to investigate the role of factors that impact green marketing adoption, which include environmental protection legislation, shortage of natural resources, changes in consumer behavior, and the attitudes of senior management towards green marketing by the food industry companies in Saudi Arabia.

\subsubsection{Environmental Protection Legislation}

Over the past two decades, many environmental laws and regulations have been enacted in industrialized countries to address the environmental problems that emerged from production processes such as local smog, groundwater contamination and regional acid rain (Grag, 2015). Although regulatory legislation has had an impact on environmental protection, it has caused some conflicts between the country's environmental and economic objectives. Therefore, the general environmental protection strategies should be subject to a number of criteria: to have a clear role toward achieving the environmental objectives, to be effective in terms of social cost, to contribute to providing necessary information to government agencies, to be easily applied and controlled; and finally, the extent to which they provide positive support in industry (AlFuqaha and AlSaifi, 2015; Carcasov et al., 2017). In this regard, Saudi Government has a framework of laws aimed at reducing the production of harmful products; for example, the ban on the bags made of plastic for restaurant and for fast foods (Alam et al., 2012).

\subsubsection{Consumer Behavior}

Customers expect companies to be socially responsible in all their practices, and companies that act unethically towards the environment will be boycotted by consumers (Widyastuti \& Santoso, 2016). Survey results showed that customers in the United States prefer choosing products from environmentally friendly companies if they have similar costs to their alternatives (Caprita, 2015). However, the vision remains unclear in determining consumer behavior, whereas a study conducted in Romania found that it was unclear to what extent consumers are willing to accept a higher price of environmentally friendly products if cheaper products are available. Legislation in this area exerts considerable pressure on companies, and the impact of this pressure transfers to customers, thereby affecting consumer purchasing behavior. Emphasis should be placed on directing messages to customers highlighting the social, environmental and ethical benefits of products, in order to set new targets to increase the customer satisfaction strategy (Kirgiz, 2016). 


\subsubsection{Shortage of Natural Resources}

Energy consumption is one of the main concerns of global economic and environmental systems due to growing concern over the impact of current energy production systems, increased energy consumption and high global demand for limited energy resources (Caprita, 2015; Kirgiz, 2016). General determinants and political systems have limited consideration for the sale and production of alternative energy. Organizations face difficulty in obtaining the raw materials necessary to conduct their production processes, as well as numerous other problems in transporting production materials, in addition to an increase in their prices as well as an increase in taxes on these resources, such as: gas, electricity, fuel, and timber. Therefore, green marketing is considered an important issue today to preserve the environment for future generations (AlFuqaha and AlSaifi, 2015).

\subsubsection{Attitudes of Senior Management}

Managers are always searching for ways to improve sustainable performance in organizations and create strategies and organizational structures to improve the social performance of organizations (Dibb et al., 2005). Managers need to know how sustainability performance affects the long-term profitability of the company, whereas senior management directives towards sustainable development and social responsibility are one of the important pillars for the implementation of green marketing strategies (AlFuqaha \& AlSaifi, 2015).

\section{Research methodology}

\subsection{Introduction}

The study sought to investigate the factors that affect the adoption of the concept of green marketing in Saudi Food companies; and the level of their adoption. The resources of the primary data were collected using survey questionnaire method which was designed based on AlFuqaha and AlSaifi (2015) and distributed to the marketing managers of the Saudi food companies. Descriptive Statistical Techniques and inferential statistics method that included regression analysis were used to test the research hypotheses.

\subsection{Research instrument}

The questionnaire contains three main sections. The first section included (3) demographic variables. The second section included (16) items that measure the level of corporate adoption of the green marketing concept (dependent variables) which consist of four marketing mix elements (represented by the product, pricing, distribution and promotion concept); The third section included (13) items that measure four factors (independent variables) affecting the adoption of the green marketing concept: environmental protection legislation, shortage of natural resources, consumer behavior, and the attitudes of senior management toward green marketing. Respondents were asked to read each item and select one of the choices as follows: - Score 5: For the (strongly agree); - Score 4: For the (agree); Score 3: For the (neutral); - Score 2: For the (disagree); - Score 1: For the (strongly disagree).

\subsection{Population and Sample}

The research population includes all of the companies working in the food industry in Jeddah, which, based on available data, consisted of (85) companies (Ministry of Commerce and Investment, 2016). A simple random sample, consisting of (70) companies, were selected from the research population. (75) questionnaire forms were distributed; and was able to return back around (70) valid questionnaire form from the target sample of the study. The characteristics of the sample of the study are presented as shown in table (1) below

Table (1) The Characteristics of the Companies

\begin{tabular}{|l|l|l|}
\hline Characteristics & Frequency & Percentages \% \\
\hline 1.years of experience & & \\
\hline Less than 5 years & 35 & 50.0 \\
\hline 5- to less than 10 & 28 & 40.0 \\
\hline 10-to less than 15 & 7 & 10.0 \\
\hline 2.type of industry & & \\
\hline Food products & 59 & 84.3 \\
\hline Drinks & 11 & 15.7 \\
\hline 3.Size of employees & & \\
\hline 5- to less than 10 & 11 & 15.7 \\
\hline 10-to less than 15 & 25 & 35.7 \\
\hline 15 and more & 34 & 48.6 \\
\hline
\end{tabular}


Results in table (1) present the characteristics of food industry sample of the study. It showed that majority of food companies $(50.0 \%)$ have experience in this field for less than 5 years, while $(40.0 \%)$ of the companies have from (5-to less than 10) years, whereas $(10.0 \%)$ have experience between (10-to less than 15) years. In addition, majority of companies with (84.3\%) are classified as food products companies, while drink product companies were only (15.7\%). Concerning the size of employees, results showed that there are about $(15.7 \%)$ of the companies' employees size is between (5-to less than 10), whereas (35.7\%) of employees size is between (10- to less than 15), while the majority with $(48.6 \%)$ of employees size is 15 employee and more.

\section{3. tool validity}

As shown in Table (2), the total Cronbach's alpha for the study fields was above (0.60) which leads to the stability of the results of this study; and the overall survey questionnaire method reliability was reaching (0.881) which was highly sufficient to guarantee that the questionnaire method has a very high reliability.

Table (2): Cronbach's Alpha for the Study Dimensions

\begin{tabular}{|l|l|l|}
\hline Dimensions & $\begin{array}{l}\text { No of } \\
\text { items }\end{array}$ & $\begin{array}{l}\text { Cronbach's Alpha } \\
\text { coefficient }\end{array}$ \\
\hline Dimension One: the level of adoption of Green Marketing. & 16 & 0.906 \\
\hline $\begin{array}{l}\text { Dimension two: the factors that affect the adoption of the concept of } \\
\text { green marketing. }\end{array}$ & 13 & 0.650 \\
\hline Overall reliability & 29 & 0.881 \\
\hline
\end{tabular}

\section{Analysis of the Results}

\subsection{Section one: descriptive statistics}

The main objective behind conducting the descriptive statistics is to assess the participants responses with regard to the level of adoption of green marketing in Saudi food companies, and the factors that have an effect on the adoption of green marketing. To conduct data analysis, the means, and standard deviations are used. The results of this analysis are presented as in the following tables:

Table (3): Participants responses with regard to the level of adoption of green marketing in Saudi food companies

\begin{tabular}{|c|c|c|c|c|}
\hline Item No. & Green marketing variables & \multirow{2}{*}{ Means } & \multirow{2}{*}{$\begin{array}{l}\text { Standard } \\
\text { deviation }\end{array}$} & \multirow{2}{*}{ Ranking } \\
\hline \multicolumn{2}{|l|}{ Products } & & & \\
\hline 1 & $\begin{array}{l}\text { The company is conducting organic improvement processes } \\
\text { to ensure the cost efficiency of the product and reduce in the } \\
\text { long term. }\end{array}$ & 2.81 & 0.95 & 5 \\
\hline 2 & The Company uses recycled raw materials. & 2.17 & 0.80 & 6 \\
\hline 3 & $\begin{array}{l}\text { There is efficiency in the energy used in the production } \\
\text { process. }\end{array}$ & 2.97 & 0.82 & 3 \\
\hline 4 & $\begin{array}{l}\text { There is reduce toxic or harmful emissions from the } \\
\text { production process. }\end{array}$ & 2.91 & 0.78 & 4 \\
\hline 5 & Packaging products are recyclable. & 3.21 & 0.95 & 2 \\
\hline 6 & $\begin{array}{l}\text { The product is safe to use and does not harm the health and } \\
\text { life of the consumer. }\end{array}$ & 3.67 & 0.86 & 1 \\
\hline \multicolumn{5}{|c|}{ 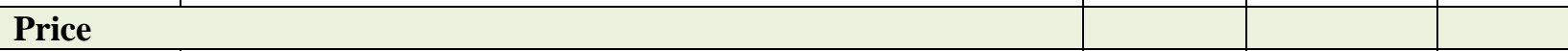 } \\
\hline 7 & $\begin{array}{l}\text { Prices of products determined by the value obtained and } \\
\text { recognized by the buyer. }\end{array}$ & 2.80 & 1.03 & 3 \\
\hline 8 & $\begin{array}{l}\text { Price premiums obtained because the production process is } \\
\text { considered a sustainable process. }\end{array}$ & 3.06 & 0.83 & 1 \\
\hline 9 & Costs are reduced to keep pace with competitors in price. & 3.13 & 0.92 & 2 \\
\hline \multicolumn{5}{|c|}{ ( } \\
\hline 10 & $\begin{array}{l}\text { There is an economy in the size of fuel material used in the } \\
\text { distribution process. }\end{array}$ & 2.61 & 0.86 & 2 \\
\hline 11 & $\begin{array}{l}\text { The process of distributing products takes place within } \\
\text { efficient and short distances. }\end{array}$ & 2.73 & 0.92 & 1 \\
\hline 12 & $\begin{array}{l}\text { Use of less harmful transportation in the process of } \\
\text { transporting and distributing products. }\end{array}$ & 2.43 & 1.02 & 3 \\
\hline
\end{tabular}




\begin{tabular}{|l|l|l|l|l|}
\hline Promotion & & & \\
\hline 13 & $\begin{array}{l}\text { The company is working to increase market awareness of } \\
\text { green products - environment-friendly. }\end{array}$ & 2.44 & 0.63 & 4 \\
\hline 14 & $\begin{array}{l}\text { Provide sufficient information about the product and the } \\
\text { company to introduce environmental benefits into the } \\
\text { products. }\end{array}$ & $\begin{array}{l}\text { The company carries out promotional campaigns to convince } \\
\text { the consumer to buy green products. }\end{array}$ & 2.77 & 0.96 \\
\hline 15 & $\begin{array}{l}\text { Provides motivate the consumer to purchase the green } \\
\text { product. }\end{array}$ & 2.90 & 0.93 & 2 \\
\hline 16 &
\end{tabular}

The results in table (3) present participants' level of adoptions of green marketing in Saudi food companies, it could be noticed that the overall mean value of participants responses regarding the level of adoption of green marketing is weak as mean value reached (2.83).

Table (4) Participants responses with regard to the factors that impact the adoption of green marketing in Saudi food companies.

\begin{tabular}{|c|c|c|c|c|}
\hline $\begin{array}{l}\text { Item } \\
\text { No. }\end{array}$ & Factors & Means & Standard & Ranking \\
\hline \multicolumn{5}{|c|}{ Environmental protection legislation } \\
\hline 1 & $\begin{array}{l}\text { There are clear and strict laws and regulations for production } \\
\text { waste. }\end{array}$ & 2.94 & 0.85 & 2 \\
\hline 2 & $\begin{array}{l}\text { There are suitable places to destroy production waste and } \\
\text { ensure no toxic and harmful leaks to the environment. }\end{array}$ & 2.93 & 0.84 & 3 \\
\hline 3 & $\begin{array}{l}\text { Industrial licenses include field and laboratory tests and tests } \\
\text { related to human safety and the environment due to } \\
\text { manufacturing processes. }\end{array}$ & 3.94 & 0.61 & 1 \\
\hline 4 & $\begin{array}{l}\text { The Government provides a system of incentives for } \\
\text { producers in the optimal use of energy and resources. }\end{array}$ & 2.09 & 0.85 & 4 \\
\hline \multicolumn{5}{|c|}{ Shortage of natural resources } \\
\hline 5 & $\begin{array}{l}\text { There is a difficulty in obtaining raw materials for } \\
\text { production processes. }\end{array}$ & 3.54 & 0.96 & 3 \\
\hline 6 & $\begin{array}{l}\text { There are problems in the process of transporting raw } \\
\text { materials. }\end{array}$ & 3.77 & 0.80 & 2 \\
\hline 7 & $\begin{array}{l}\text { The High prices of raw materials such as gas, fuel, } \\
\text { electricity, wood ... etc.) }\end{array}$ & 4.37 & 0.62 & 1 \\
\hline \multicolumn{5}{|c|}{ consumer behavior } \\
\hline 8 & $\begin{array}{l}\text { Consumers want to buy environmentally friendly products } \\
\text { such as organic products. }\end{array}$ & 2.77 & 0.92 & 1 \\
\hline 9 & $\begin{array}{l}\text { There is growth in demand for environmentally friendly } \\
\text { products or products include on environmentally friendly } \\
\text { properties. }\end{array}$ & 2.66 & 0.80 & 3 \\
\hline 10 & $\begin{array}{l}\text { The consumer is aware of the brands of environmentally } \\
\text { friendly products and their ability to distinguish them. }\end{array}$ & 2.56 & 0.85 & 4 \\
\hline 11 & Consumer has loyalty to environmentally friendly products. & 2.69 & 0.96 & 2 \\
\hline \multicolumn{5}{|c|}{ Attitudes of senior management } \\
\hline 12 & $\begin{array}{l}\text { Senior management has a direct and personal interest in } \\
\text { green marketing. }\end{array}$ & 2.34 & 0.81 & 1 \\
\hline 13 & $\begin{array}{l}\text { The company's senior management works to develop policies } \\
\text { that support green marketing practices. }\end{array}$ & 2.21 & 0.95 & 2 \\
\hline
\end{tabular}

Marketing Table (4) showed the factors that impact the adoption of green marketing in Saudi food companies. Results showed that, although majority of participants agreed that the industrial licenses include field and laboratory tests, there is no system of incentives provided by the government for producers to follow the optimal use of energy and resources. In addition, the study found that, the shortage of natural resources is considered as one of the most basic factors that causes problems to the adoption of the concept of green marketing in food companies, in particularly, the high prices of raw materials such as gas, fuel, electricity, and problems in the process of transporting raw materials. 
With regard to impact of change of consumers behavior on the adoption of the concept of green marketing in food companies, results found that the change in consumers behavior has no clear effect on the adoption of green marketing. With regard to the effect of senior management, the study showed that majority of participants don't agree that senior management has a direct and personal interest in green marketing, nor it works to develop policies that support green $g$ practices.

\subsection{Section two: Results of Testing Research Hypotheses}

Saudi food industry companies"

Table (5): Result of simple linear regression to examine the effect of environmental protection legislations on the adoption of green marketing in Saudi food companies

\begin{tabular}{|c|c|c|c|c|c|c|}
\hline Model & $\begin{array}{l}\text { Coefficients } \\
\text { (B) }\end{array}$ & Beta & T-test & P-value & F-statistics & $\begin{array}{l}\mathrm{P} \text { - } \\
\text { value }\end{array}$ \\
\hline Constant & 17.30 & & $3.456 * *$ & 0.001 & \multirow[b]{2}{*}{$32.987 * *$} & \multirow{3}{*}{0.00} \\
\hline $\begin{array}{l}\text { Environmental protection } \\
\text { legislation }\end{array}$ & 2.377 & 0.572 & $5.743 * *$ & 0.00 & & \\
\hline $\mathrm{R}=0.572$ & \multicolumn{3}{|l|}{$\mathrm{R}^{2}=0.327$} & \multicolumn{2}{|c|}{ Adj. $R^{2}=0.317$} & \\
\hline
\end{tabular}

** indicated that the test is statistically significant at the (0.01) level

the value of the regression coefficient of the independent variable (environmental protection legislation) is equal to (2.337), and T-test statistics is significant at the (0.01) level, this indicated that there is a significant effect of environmental protection legislation on the adoption of green marketing in Saudi food industry companies; hence, the null hypothesis is rejected.

-(H2): stated that "Shortage of natural resources has no significant effect on adoption green marketing in Saudi food industry companies".

Table (6) Result of simple linear regression to examine the effect of shortage of natural resources on the adoption of green marketing in Saudi food industry companies

\begin{tabular}{|c|c|c|c|c|c|c|}
\hline Model & Coefficients (B) & Beta & T-test & P-value & F-statistics & P-value \\
\hline Constant & 65.658 & & 10.05 & 0.00 & \multirow[b]{2}{*}{$9.671 * *$} & \multirow[b]{2}{*}{0.003} \\
\hline $\begin{array}{lll}\begin{array}{l}\text { Shortage } \\
\text { resources }\end{array} & \text { of natural } \\
\end{array}$ & -1.718 & -0.353 & -3.11 & 0.003 & & \\
\hline$R=0.353$ & \multicolumn{3}{|l|}{$\mathrm{R}^{2}=0.125$} & \multicolumn{3}{|c|}{ Adj. $R^{2}=0.112$} \\
\hline
\end{tabular}

** indicated that the test is statistically significant at the (0.01) level

Result in table (6) showed the value of the regression coefficient of the independent variable (shortage of natural resources) reaching (-1.718), and T-test value is significant at the (0.01) level, this proved that there is a significant and negative effect of shortage of natural resources on the adoption of green marketing in Saudi food companies. Hence, as shortage of natural resources increases, this will lead to less adoption of green marketing in food companies; therefore, the null hypothesis is rejected.

-(H3) stated that "consumer behavior has no significant effect on adoption green marketing in Saudi food industry companies".

Table (7) Results of simple linear regression to examine the effect of consumer behaviour on the adoption of green marketing in Saudi food industry companies

\begin{tabular}{|l|l|l|l|l|l|l|}
\hline Model & $\begin{array}{l}\text { Coefficients } \\
(\mathrm{B})\end{array}$ & Beta & T-test & P-value & F-statistics & P-value \\
\hline Constant & 39.810 & & 9.377 & 0.00 & \multirow{2}{*}{1.979} & 0.16 \\
\hline Consumer behavior & 0.541 & 0.168 & 1.407 & 0.16 & & \\
\cline { 1 - 2 }$=0.168$ & $\mathrm{R}^{2}=0.028$ & & \\
\hline
\end{tabular}

Result of Table (7) showed that the value of the regression coefficient of the independent variable (changes in consumer behaviour is reaching (0.541), and T-test value was not significant as the P-value is greater than (0.05) level. Therefore, there is no significant effect of the changes in consumers behaviour on the adoption of green marketing in Saudi food companies. Hence, this result doesn't provide statistical evidence to reject (H3), therefore, it was accepted.

-(H4): stated that "An attitude of senior management has no significant effect on adoption green marketing in Saudi food industry companies". 
Table (8) Results of simple linear regression to examine the impact of senior management attitudes on the adoption of the concept of green marketing in Saudi food companies

\begin{tabular}{|c|c|c|c|c|c|c|}
\hline Model & Coefficients (B) & Beta & T-test & P-value & F-statistics & P-value \\
\hline Constant & 30.674 & & $12.464 * *$ & 0.00 & \multirow[b]{2}{*}{$41.852 * *$} & \multirow[b]{2}{*}{0.00} \\
\hline $\begin{array}{l}\text { Attitudes of senior } \\
\text { manager }\end{array}$ & 3.272 & 0.617 & $6.469 * *$ & 0.00 & & \\
\hline $\mathrm{R}=0.617$ & \multicolumn{3}{|l|}{$\mathrm{R}^{2}=0.381$} & \multicolumn{3}{|c|}{ Adj. $R^{2}=0.372$} \\
\hline
\end{tabular}

The value of the regression coefficient of the independent variable (senior management attitude) is reaching (3.272), and T-test value is significant as the P-value is less than (0.01) level. So, this result confirmed that there is significant and positive effect of senior management attitudes on the adoption of green marketing in Saudi food companies. Hence, the null hypothesis is rejected.

\section{Discussion and Recommendations}

\subsection{Discussion of the level of Saudi food companies adopting the concept of green marketing}

The level of Saudi food companies' adoption of the green marketing concept is generally low in all elements of marketing mix (product, price, promotion and place). This result is consistent with Alam et al., (2012) study; which indicated that the level of adoption of green marketing in Saudi Arabia is still low and the idea is still new to the greater population. In addition, this finding is consistent with Caprita (2015) which stated that despite the increasing demand for greener products, the number of companies using green marketing strategies is still very low. The overall response was weak (2.83) which means the companies' adoption of the concept of green marketing is not matching the new global direction in marketing.

-Product: Majority of participants disagree that the food companies use recycled raw materials, which indicated that they lack the technology of recycling raw materials. As a result, not all food companies are conducting recycling the packaging products as mean is (3.21). The only positive thing is that, most food companies are aware about their products safety as not to harm the health and life of the consumers; which is consistent with AlFuqaha and AlSaifi (2015).

-Price: participants don't provide clear cut answer about the adoption of green marketing in pricing the product: whether to determine the prices of products by the value obtained by the buyer or using price premiums because the production process is considered sustainable as mean reached $(2.80,3.06,3.13)$ which all indicated that the participants responses stand at the cross road. As a result, developing green pricing strategy is mandatory in food industries companies.

-Place: participants were doubt if there is an economy in the size of fuel material used in the distribution process, as the mean value is (2.61); whereas the participants don't confirm that the process of distributing products takes place within efficient and short distances, as the mean value is (2.73). Since green place is the logistics management to reduce the transport emissions, it is suggested to reduce CO2 emissions and increase their use of local suppliers (Alam et al., 2012).

-Promotion: Majority of participants don't agree that the food companies are working to increase market awareness of green products that is environment friendly as mean is (2.44); participants do agree nor disagree about that the company carries out promotional campaigns to convince the consumer to buy green products. Therefore, it is suggested to promote food safety information and the benefits of green products to the public through the media. To conclude, elaborating a green marketing plan depends on establishing the perfect mix in order to maximize profits while respecting sustainability principles (Caprita, 2015; Wood, 2008).

\subsection{Discussion of Factors effecting the adoption of green marketing concept}

The results of the hypothesis test show a strong significant relationship to all independent study variables or factors which include legislations for pollution and environmental protection, shortage of natural resources, changes in consumer behavior, and the attitudes of senior management towards green marketing - with the adoption of green marketing by Saudi food companies except the change in consumer behavior; no strong relationship to this variable was shown with adopting the concept of green marketing; which is consistent with AlFuqaha and AlSaifi (2015). Most of the path coefficients are significant at $1 \%$ level providing strong support for all the hypothesized relationships. The results of multiple regression confirm that the factors included in the model are effective to estimate the changes on the implementation of green marketing by (58.0\%) approximately which is consistent with AlFuqaha and AlSaifi (2015). 
The first and the most important factor that has an effective impact on green marketing is senior management attitudes. Then environmental protection legislation; then the lack of natural resources; the last variable is the consumer behavior, it was noticed that this factor has no significant effect on the implementation of green marketing in Saudi food companies.

\section{- Environmental protection legislation}

Majority of participants agreed that the industrial licenses include field and laboratory tests related to human safety and the environment as mean is (3.94); which is consistent with Baker and Hart (2008) who argued that companies have been adopted green marketing activities under the pressure of legislative measures. However, some companies implement strict regulations for production waste, while other don't as mean is (2.94) that means there is no seriousness within the environmental protection legislation to compel companies to oblige to specify suitable places to destroy production waste and ensures no harmful leaks to the environment. therefore, there is a need for legislations to push the companies to adopt, monitor and protect these practices, with the availability of a motivation system to encourage the companies conduct sustainable practices.

\section{-Shortage of natural resources}

Majority of participants strongly agreed that high prices of raw materials such as gas, fuel and electricity have great effect on the adoption of green marketing as mean is (4.37). In addition, majority of participants agreed that there are problems in the process of transporting raw materials (3.77) which indicated that there is a negative and significant correlation relationship between the dependent and the independent variables. This means as the shortages of natural resources increases, this will impede the implementation of green marketing in Saudi food companies. Hence, it is suggested that government must encourage Saudi food companies to adopt a sustainable plan in using the natural resources.

\section{-Consumer behavior}

Participants were neither agree nor disagree that consumers want to buy environmentally friendly products such as organic products as mean is (2.77). In addition, participants have neutral thought about the consumer loyalty to environmentally friendly products as mean is (2.69). These results confirmed that there is lack of marketing strategies that oriented towards consumers to buy environmentally friendly products such as organic products.

Results showed that there is no statistically significant correlation between the change in consumer behavior and the adoption of green marketing in Saudi food companies. This means that the change in consumer behavior has nothing to do with the implementation of green marketing which is consistent with AlFuqaha and AlSaifi (2015). However, this finding is contrasting the literature in green marketing which asserted the role of consumer attitude who directs both the consumption and the production (Kirgiz, 2016; Widyastuti \& Santoso, 2016).

\section{-Attitudes of senior management}

Majority of participants don't agree that senior management has a direct interest in green marketing as mean is (2.34); which might be attributed to the high cost of implementing green marketing. In addition, majority of participants don't agree that the company's senior management works to develop policies that support green marketing practices as mean is (2.21). This result indicated that food companies are far a way to develop policies that support green marketing due to lack of high-quality labor which is consistent with AlFuqaha and AlSaifi (2015).

Results confirm that the changes in senior management attitudes are capable to estimate the changes on the implementation of green marketing by (38.0\%) approximately. This indicated that as senior management change positively, it will affect positively on implementing green marketing in Saudi food companies; which is consistent with literature which affirmed that managers are extremely important agents for deciding the organizational strategy and keeping environment protection (Dibb et al., 2005).

\section{Recommendations}

In an efficient green marketing strategy of food companies, the four Ps: product, price, place, and promotion, should be based on sustainability principles (economic, social and environmental) in order to achieve competitive advantage. 2. There is a need to enact legislation and develop systems that can protect environment from pollution; and limit loss of resources to provide a clean and secured environment. 3. There is a need to develop consumer's awareness for green products to build their demand, trust and loyalty for such products. 4. It is necessary for senior managers to include green marketing in its priorities. And to achieve competitive advantage through viewing adoption of green marketing as a major long-term investment opportunity with long-term benefits; and not to focus on achieving growth outcomes or quick revenue on the short run. 


\section{References}

Alam, A., Almotair, M., \& Gaadar, K. (2012). Green marketing in Saudi Arabia: Rising challenges and opportunities, for better future. Journal of Applied Social Psychology, 8(11), 144-151.

Anand, V. (2014). Green marketing and its importance for companies. International Journal of Research in Commerce and Management, 4(8), 46-48.

Al fuqaha, P., \& Al Saifi, M. (2015). Factors influencing the level of adoption of food industry companies for sustainable marketing in Palestine. The Jordanian Journal of Business Administration (Jordan), 11(2), 409-381.

Baker, M. \& Hart, S. (2008). The Marketing Book. Oxford, United Kingdom: Butterworth-Heinemann.

Caprita, D. (2015). The importance of green marketing for the future businesses. Competitiveness Of Agro - Food \& Environmental Economy, 242-254.

Čerkasov, J., Huml, J., Vokáčová, L., \& Margarisová, K. (2017). Consumer's attitudes to corporate social responsibility and green marketing. Acta Universitatis Agriculturae et Silviculturae Mendelianae Brunensis, 65(6), 1865-1874.

Dibb, S., Simkin, L., Pride, W. M., \& Ferrell, O. C. (2005). Marketing: Concepts and strategies (p. 850). Houghton Mifflin.

Eneizan, B., Abd. Wahab, A., \& Bustaman., U. (2015). Effects of green marketing strategy 4ps on firm performance. International Journal of Applied Research, 1(12), 821-824.

Foster, A. (2013). Sustainability: Best practices in the food industry. UW-L Journal of Undergraduate Research, 1(16), $1-9$.

Garg, A. (2015). Green marketing for sustainable development: An industry perspective. Sustainable Development, (23), 301-316.

Kirgiz, A. (2016). The Marketing Book. Basingstoke, United Kingdom: Palgrave Macmillan.

Kotler, P., \& Armstrong, G. (1999). Principles of marketing. (8th ed). N. Carolina: Pearson.

Sima, V. (2014). Green behavior of the Romanian consumers. Economic Insights: Trends and Challenges, 3(66), 77-89.

Solaiman, M., Osman, A., \& Mohd, S. (2015). Green marketing: A marketing mix point of view. International Journal of Business and Technopreneurship, 5(1), 87-98.

Widyastuti, S., \& Santoso, B. (2016). Green marketing, ASEAN Marketing Journal, 8(8), 104-115.

Wood, A. (2008). The Marketing Book. Cambridge, United Kingdom: Cambridge University Press. 